\title{
GENERA PLEUROTHALLIDINARUM: THE ERA OF CARLYLE LUER
}

\author{
AdAm P. KARREMANS ${ }^{1,2,3} \&$ Nicolas DaVin ${ }^{2}$ \\ ${ }^{1}$ Lankester Botanical Garden, University of Costa Rica, P.O. Box 302-7050 Cartago, Costa Rica \\ ${ }^{2}$ Naturalis Biodiversity Center, Leiden, The Netherlands \\ ${ }^{3}$ Author for correspondence: adam.karremans@ucr.ac.cr
}

\begin{abstract}
The era or Carlyle Luer, which currently comprehends the forty-two years since the publication of the first Icones Pleurothallidinarum in 1975, has witnessed a true revolution in the knowledge and understanding of the species belonging to the subtribe. When Luer came into the scene, after more than two hundred years of Pleurothallidinae history, there were just about 4,000 published taxon names in the subtribe, including 52 generic names and barely 1,650 accepted species. Today there are 12,133 published taxon names, including 164 generic names, and 5,114 currently accepted species belonging to the subtribe. This means that during the Luerian era published taxa, accepted or otherwise, were tripled. During this period the rate of species description has been about 85-90 species per year, and there is nothing suggesting this rate will slow down anytime soon. If this trend is maintained, as we believe it will, by the year 2026, the subtribe will include close to six thousand accepted species.
\end{abstract}

Key words: Lepanthes, Masdevallia, Octomeria, Pleurothallidinae, Pleurothallis, Stelis

Introduction. An era is defined as a long and distinct period of history with a particular feature or characteristic; there is no doubt that the decades Carlyle August Luer has dedicated to the study of Pleurothallidinae mark a discrete and well-defined period of time. The Luerian era, which currently comprehends the 42 years since the publication of the first Icones Pleurothallidinarum (Luer 1975), has witnessed a true revolution in the knowledge and understanding of the species belonging to the subtribe. His work has been guided by a strong conviction that the only way to tackle this ungraspable group is to set solid bases by illustrating and characterizing everything, and making this information universally accessible and usable. His thirty-two published monographs on the Pleurothallidinae are the monument to his cause, and will be the reference for generations to come. It is important, nonetheless, to examine the historical steps that lead up to the Luerian era (Fig. 1).

The oldest published reference to a species belonging to Pleurothallidinae must be that of Jacobus Theodorus Tabernaemontanus, who in 1625 proposed the name "Viscum Indicum" (Indian mistletoe), for a species which is difficult to assign specifically to any current genus (Fig. 2). The first validly published species attributable to the Pleurothallidinae were described by Nikolaus Joseph von Jacquin in his Enumeratio
Systematica Plantarum published in 1760 . Von Jacquin was born in Leiden, The Netherlands, where he studied medicine and botany at Leiden University. Amongst other positions, he was employed by the Schönbrunn palace in Vienna, Austria, and it is in their service that he was sent to the West Indies and Central America to collect plants (Ossenbach 2016). He published many of his collections as novelties, including a handful of orchids. Two of those, Epidendrum ophioglossoides Jacq. and E. ruscifolium Jacq, being pleurothallids. Both species, based on the illustrations prepared by the French monk Charles Plumier in late XVII century and published in 1758 (Plumier 1758: 171-172, tab. 176), would turn out to be highly significant historically as they were later selected as types of the genera Stelis Sw. and Pleurothallis R.Br. respectively.

By the end of the $18^{\text {th }}$ century, about 35 species belonging to the Pleurothallidinae had been named, most of them within the genus Epidendrum L. Already by 1794 the first generic names attributable to the species of the subtribe would appear, Humboldtia Ruiz \& Pav. and Masdevallia Ruiz \& Pav. They were shortly followed by two other well-known genera, Lepanthes Sw. and Stelis Sw., published in 1799 and 1800 respectively, and not too long after by the creation of Pleurothallis R.Br. and Octomeria R.Br., in 1813. Several additional generic names would 


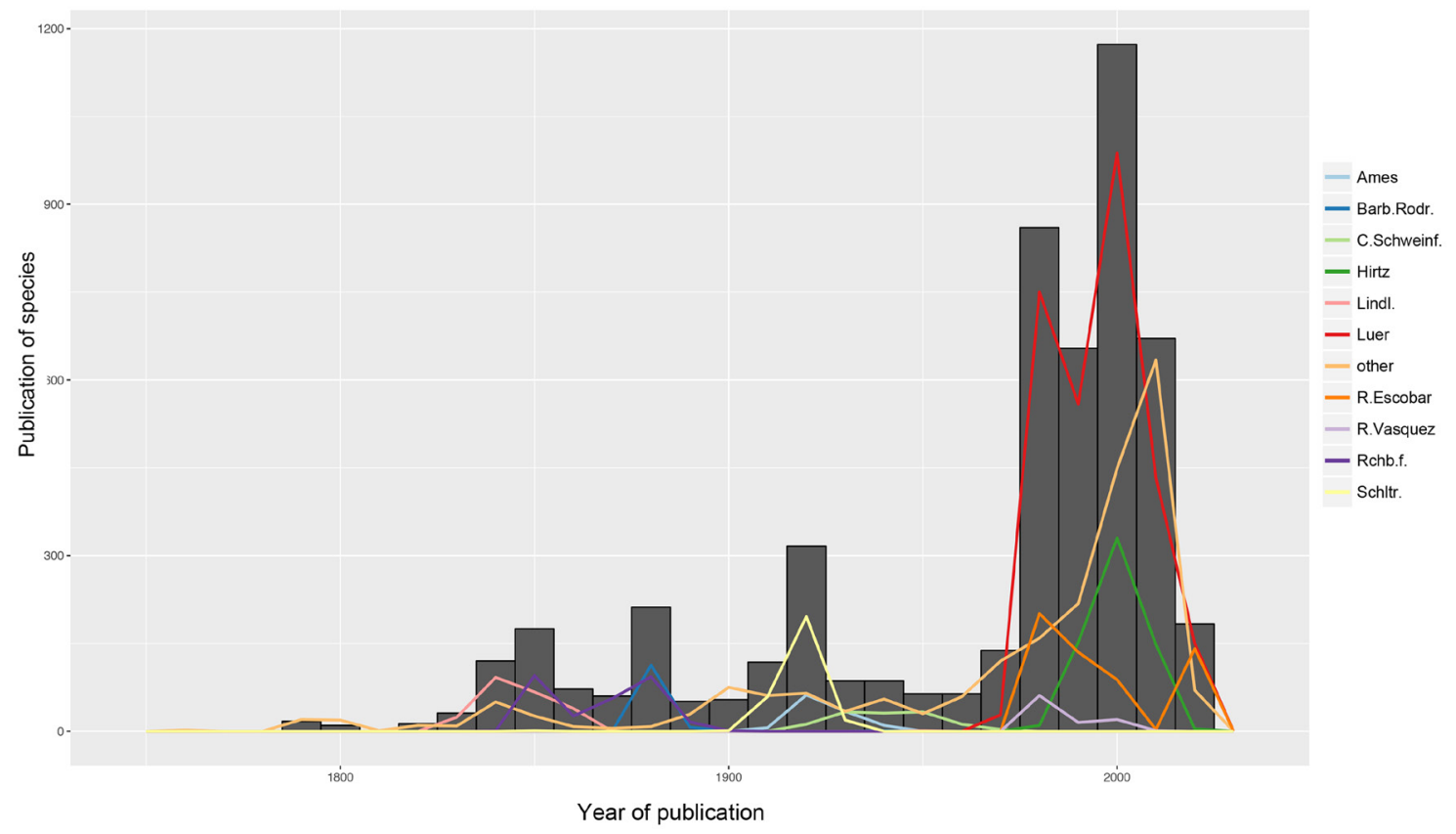

FIGURE 1. Historial publication of Pleurothallidinae species showing the relative influence of the top publishing authors in the subtribe.

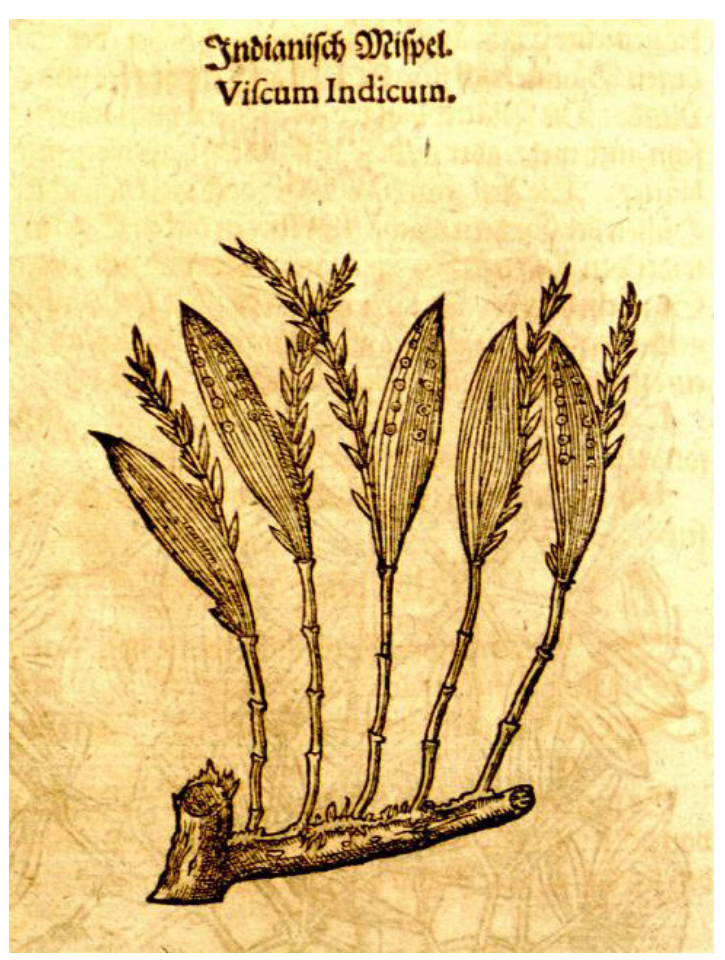

FIgURE 2. Viscum Indicum. The first Pleurothallidinae species depicted in literature, published by Jacobus Theodorus Tabernaemontanus in 1625. appear in the subsequent years, but it is these five, Lepanthes, Masdevallia, Octomeria, Pleurothallis and Stelis [with Humboldtia as a synonym], that can be considered true classics, or otherwise the traditionally accepted and most broadly used genera in the subtribe. The original five are today more than 200 years in use, and as pillars of the Pleurothallidinae will surely stand the test of time.

The $19^{\text {th }}$ century would see a steady increase in the description of Pleurothallidinae species. By the year 1899 some two-thousand published names applied to taxa belonging to the subtribe, including 13 of the currently accepted genera and just shy of 800 of the currently accepted species. Several authors contributed to this increase in pleurothallid species, but it was especially through the personal efforts of John Lindley, Heinrich Gustav Reichenbach, João Barbosa Rodrigues, Robert Allen Rolfe and Alfred Célestin Cogniaux, that the diversity of the Pleurothallidinae began to be revealed. Lindley dedicated many publications to describing species of the subtribe, especially noteworthy were his comprehensive treatments in the Edwards's Botanical Register (Lindley 1842) and Folia Orchidacea (Lindley 1859). Reichenbach filius published dozens 
of Pleurothallidinae in a plethora of publications that appeared in a less systematic fashion mostly in the periodicals Bonplandia, Flora, Linnaea and, especially The Gardeners' Chronicle which he used to showcase horticulturally valuable orchids. Barbosa Rodrigues dedicated many pages, richly accompanied with illustrations, to the pleurothallids in his Genera et Species Orchidearum Novarum (Barbosa Rodrigues 1877, 1882). While around the turn of the century, Cogniaux's integral treatment of Brazilian Pleurothallidinae would see the light, as part of the Flora Brasiliensis (Cogniaux 1896, 1906).

By the beginning of the $20^{\text {th }}$ century the popularity of the Pleurothallidinae had grown substantially, with many additional authors publishing novelties in the species-rich group. The pleurothallid scene was quickly dominated basically by three names: Friedrich Wilhelm Ludwig Kränzlin (Kraenzlin), Friedrich Richard Rudolf Schlechter, and Oakes Ames. They, like most of their predecessors, relied predominantly on collections made by a plethora of collaborators in diverse Latin American countries to study the species belonging to the subtribe. Of the twelve-hundred taxa belonging to the Pleurothallidinae published between 1908 and 1935, 85\% were authored by either Ames, Kränzlin or Schlechter.

Their paramount work was followed by a highly diverse group of authors characterized especially by a more "hands on" policy of doing research on their own collections in addition to those found in herbaria. Between 1936 and 1976, the American botanists Charles Schweinfurth, Louis Otho Williams, and of course Leslie Andrew Garay came into the pleurothallid scene. Efforts to study the Pleurothallidinae diversity locally would also spring. In Brazil, the publications of Frederico Carhlos Hoehne and Guido Pabst; in Venezuela, the works of Galfried Clement Keyworth Dunsterville and Ernesto Foldats; and in the Antilles those of Henry August Hespenheide, as well as several others.

We have historically reached the mid nineteenseventies and there are dozens of other authors that have contributed significantly to our knowledge of the Pleurothallidinae that have not been mentioned in the preceding lines. Such an oversight is, of course, not meant disrespectfully. The top taxa contributing authors are provided (Table 1).
The Pleurothallidinae of Carlyle August Luer. When Luer came into the scene, in 1975, there were barely 4,000 published taxon names in the subtribe, including 52 generic names, in more than two hundred years of Pleurothallidinae history (Tables 1-2). Today, forty-two years later, there are 12,133 published taxon names, including 164 generic names. More astonishing, however, is the fact that out of the 5,114 currently accepted species belonging to the subtribe (Karremans 2016), only around 1,650 were published before Luer's Icones Pleurothallidinarum (Fig. 3). This means that during the Luerian era published taxa, accepted or otherwise, were basically tripled.

Carlyle Luer started his taxonomical career in 1966 when he published two species belonging to the genus Triphora Nutt. (Orchidaceae). He continued working with North American terrestrial orchids until 1975, the same year he published his first works on the Pleurothallidinae. The first species belonging to the subtribe that he described were Pleurothallis cypripedioides Luer and Pleurothallis quadriserrata Luer, published in his first Icones Pleurothallidinarum under the title "Pleurothallis of Ecuador (Orchidaceae)", in the inaugural issue of journal Selbyana (Luer 1975). That first publication was very indicative of his working methods and it set the tone for what was to come. He treated twentyone species from Ecuador, and instead of publishing solely novelties he judiciously selected long-known and widely distributed species that have traditionally had a complex taxonomical history so that they could be illustrated, characterized and clarified. $\mathrm{He}$ was careful enough to illustrate each species, and always used material from the country for the illustration. To assign the names he consulted the type material and original description, and complemented that with other available literature, evaluating each case with scrutiny, including a curated list of synonyms, description and distribution. It is this method of meticulously studying the types, going through the historical literature, illustrating dozens of specimens and understanding the local floras that not only allowed for the recognition of thousands of undescribed pleurothallids, but also set strong bases for the understanding of the "old" names in the subtribe.

It is clear that Carl has not been the only author contributing to taxon description during the Luerian era, 
TABLE 1. Top contributing individual authors to taxa names in Pleurothallidinae.

\begin{tabular}{|c|c|c|c|}
\hline Author & Taxa* $^{\star}\left(\right.$ Basionyms $\left.{ }^{* \star}\right)$ & Period of Activity & Currently Accepted $^{\star * *}$ \\
\hline Luer & $5172(2909)$ & $1975-2017$ & $57 \%$ \\
\hline Hirtz & $693(644)$ & $1983-2017$ & $83 \%$ \\
\hline Schltr. & $639(276)$ & $1899-1929$ & $31 \%$ \\
\hline R.Escobar & $608(568)$ & $1978-2017$ & $87 \%$ \\
\hline M.W.Chase & $560(1)$ & 1993-2002 & $64 \%$ \\
\hline Pridgeon & $559(0)$ & 2001-2002 & $64 \%$ \\
\hline Rchb.f. & $452(288)$ & $1844-1900$ & $40 \%$ \\
\hline Lindl. & $358(223)$ & $1825-1986$ & $35 \%$ \\
\hline Archila & $354(45)$ & $1998-2016$ & $8 \%$ \\
\hline Kuntze & $299(1)$ & $1859-1891$ & $0 \%$ \\
\hline Garay & $219(73)$ & $1909-1985$ & $44 \%$ \\
\hline Barb.Rodr. & $206(121)$ & $1859-1937$ & $20 \%$ \\
\hline Ames & $199(112)$ & $1908-1942$ & $36 \%$ \\
\hline Kraenzl. & $198(69)$ & $1891-1978$ & $19 \%$ \\
\hline Karremans & $193(27)$ & $2010-2017$ & $96 \%$ \\
\hline Szlach. & $193(4)$ & $2001-2016$ & $2 \%$ \\
\hline C.Schweinf. & $184(124)$ & $1925-1970$ & $37 \%$ \\
\hline Cogn. & $160(38)$ & $1880-1986$ & $8 \%$ \\
\hline F.Barros & $133(6)$ & $1983-2015$ & $68 \%$ \\
\hline Kulak & $109(0)$ & 2006 & $0 \%$ \\
\hline R.Vásquez & $108(97)$ & $1980-2010$ & $69 \%$ \\
\hline Hoehne & $99(44)$ & $1919-1952$ & $9 \%$ \\
\hline
\end{tabular}

* Taxa includes species and subspecific categories, and includes the basionyms and combinations, regardless of validity, legitimacy and synonymy. It does not include genera or its divisions.

** Basionyms include only those of currently accepted species.

*** Currently accepted refers to names published by that author currently in usage as originally published.

TABLE 2. Taxa published in the Pleurothallidinae and the effect of Luer's contribution.

\begin{tabular}{l|c|c|c|c|r}
\hline & Time Period & Published Taxa* $^{*}$ & Accepted Species & Generic Names & Accepted Genera** $^{*}$ \\
\hline Pre-Luerian & $1760-1975$ & 4000 & 1650 & 52 & 22 \\
\hline Luerian Era & $1975-2017$ & +8000 & +3460 & 112 & 20 \\
\hline Current Total & $1760-2017$ & 12133 & 5114 & 164 & 42 \\
\hline
\end{tabular}

* Taxa includes species, genera, subspecific, and subgeneric names, regardless of validity and legitimacy.

** Modified from Karremans (2016) by the reduction of Dondodia and Kraenzlinella to the synonymy of Acianthera as proposed by Karremans et al. (2016).

in fact a total of 366 different authors have published taxa in the subtribe since Jacquin published the first. Nonetheless, of all those authors less than half have contributed with more than three names, only twenty with more than one hundred names, and Luer has been, by far, the author that contributed the most (Table 2). Between 1975 and 2017, Luer published 5,121 species, subspecies and combinations in the Pleurothallidinae.
Many by himself, but several hundred of them in collaboration (Table 3). The most frequent coauthors of his work have been Alexander Hirtz in Ecuador, Rodrigo Escobar in Colombia, and Roberto Vásquez in Bolivia. Other, more recent, collaborators include Antonio Toscano de Britto, Stig Dalström, Antonius (Ton) Sijm, Lisa Thoerle, and Jose (Pepe) Portilla, among others, together with whom he published dozens of new taxa. 


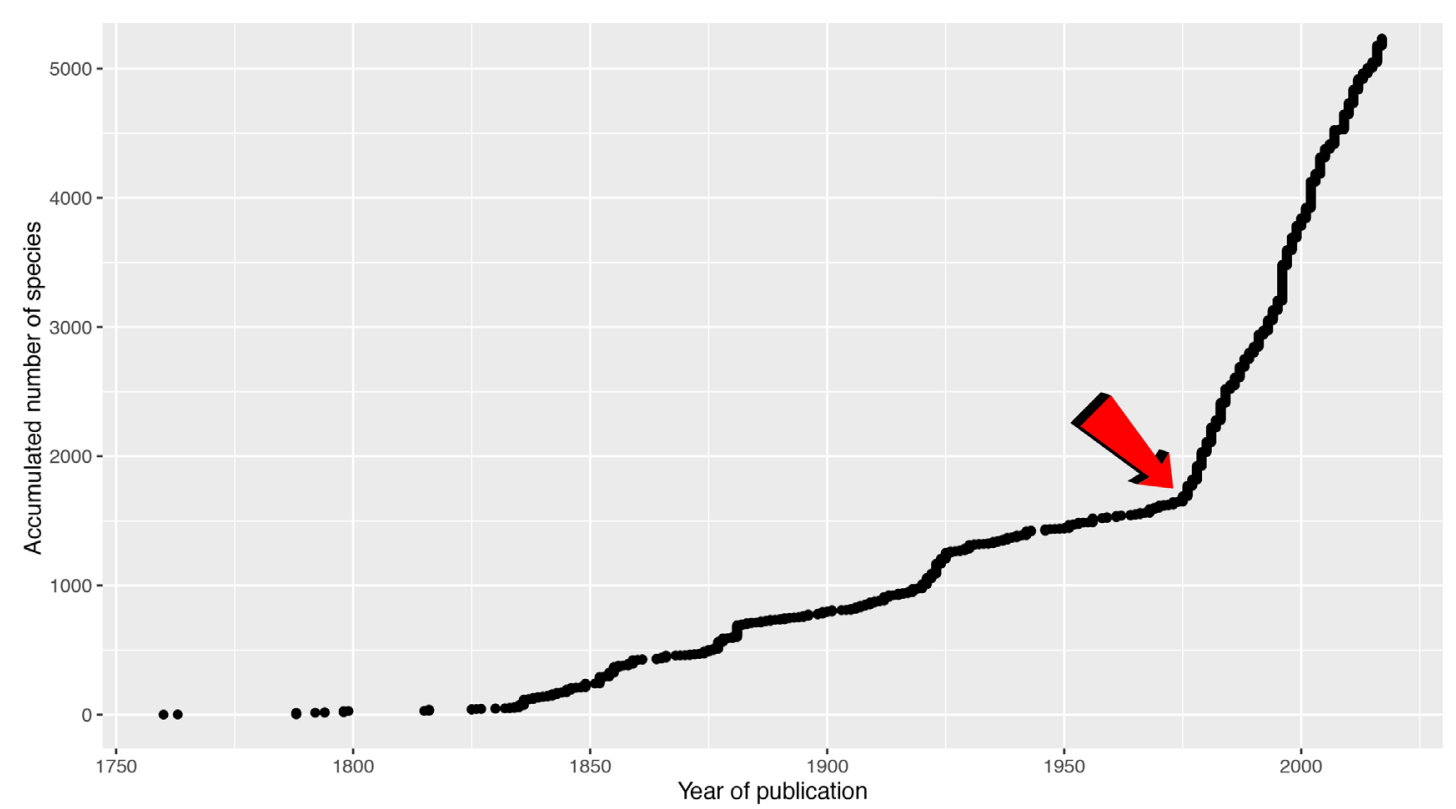

FIgURE 3. Accumulation curve of Pleurothallidinae species. The red arrow indicates the point in which the species accumulation accelerates, coinciding with the publication of Luer's first Icones Pleurothallidinarum in 1975.

What lies ahead for the Pleurothallidinae? The six most species rich genera in the Pleurothallidinae currently are Acianthera Scheidw., Lepanthes, Masdevallia, Octomeria, Pleurothallis and Stelis (Karremans 2016), and, as expected, they all show a steady increase in species numbers since the start of the Luerian era (Fig. 4). Contrary to what one would expect, the publication of monographic works for each genus has been followed by a continuous publication of additional novelties in that genus, and not by a period of silence. The monographic works on these genera have set a solid starting point allowing for a better understanding of the diversity in each genus, rather than a final account of its species. This "monograph effect" may partly explain why there is a much slower increase in some genera as compared with others. Of Octomeria, for example, Luer published a single monograph, and not only did it exclude the region where the genus is most diverse, but it was also one of the last monographs published. One of the main contributors to the increase in species numbers is the recognition of taxa previously placed under the synonymy of other species. A large number of synonyms is quite indicative of how well resolved a genus is (Fig. 5). The number of synonyms per species in Anathallis and Pabstiella, for example, is abnormally high and it
TABLE 3. Authors who contributed the highest number of basionyms of currently accepted Pleurothallidinae species.

\begin{tabular}{l|c}
\hline Author Combination & Basionyms \\
\hline Luer & 1141 \\
\hline Luer \& Hirtz & 639 \\
\hline Luer \& R.Escobar & 566 \\
\hline Rchb.f. & 271 \\
\hline Schltr. & 269 \\
\hline Lindl. & 222 \\
\hline Barb.Rodr. & 121 \\
\hline Luer \& R.Vásquez & 95 \\
\hline C.Schweinf. & 84 \\
\hline Ames & 70 \\
\hline Luer \& Sijm & 60 \\
\hline Luer \& Dalström & 54 \\
\hline O.Duque & 52 \\
\hline Garay & 49 \\
\hline Pabst & 47 \\
\hline Kraenzl. & 44 \\
\hline Luer \& Toscano & 41 \\
\hline Königer & 40 \\
\hline Ames \& C.Schweinf. & 38 \\
\hline Luer \& Andreetta & 38 \\
\hline
\end{tabular}




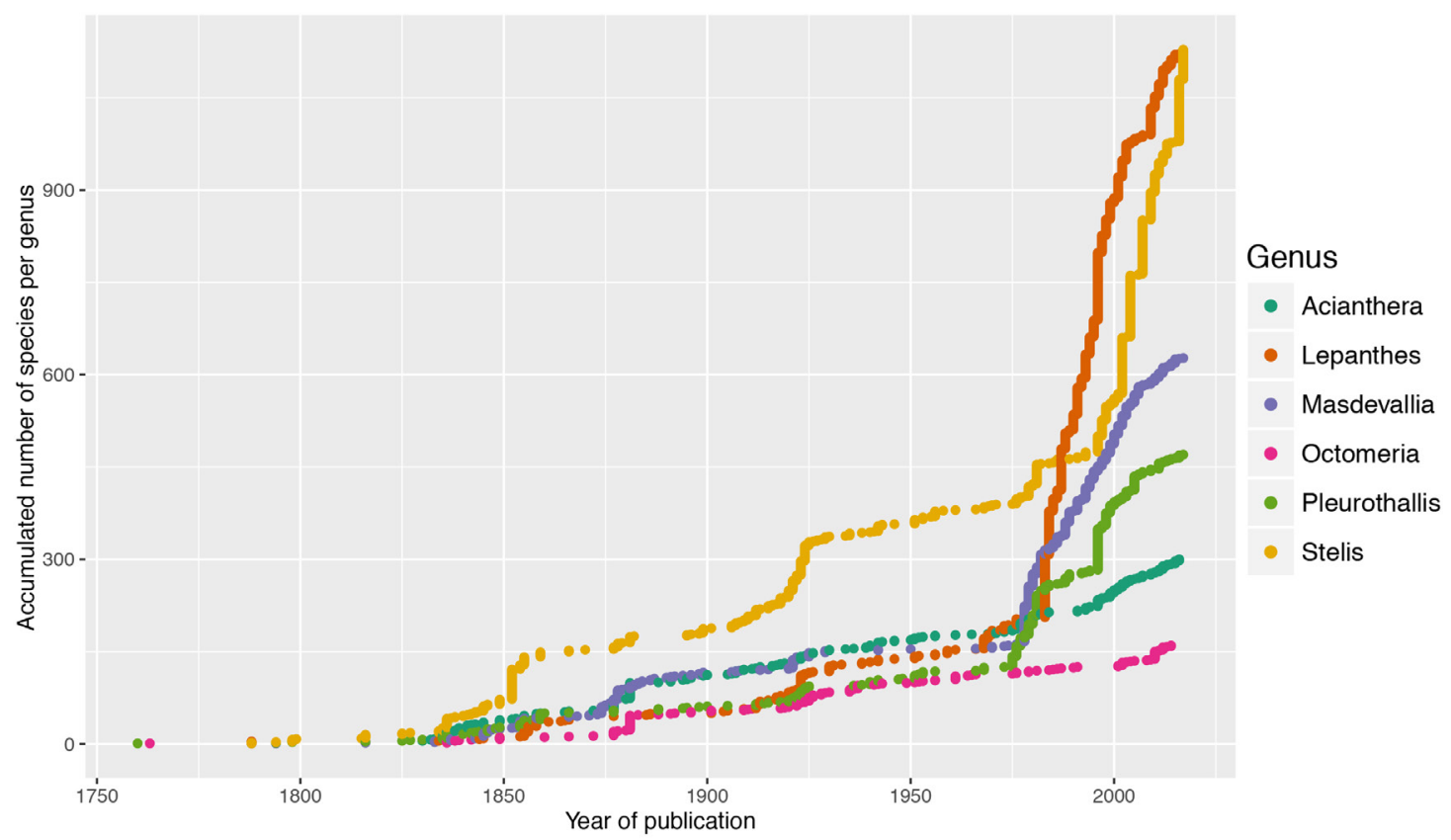

FIGURE 4. Species accumulation curve of the six most species rich genera in Pleurothallidinae.

may not be coincidental that they are among the very few genera not monographed by Luer. Masdevallia, on the contrary, has been heavily emphasized, with six monographs dedicated exclusively to the genus. The genus has traditionally attracted more attention and it is quite likely that its species are better known than those of other genera. Most of the synonyms reported per species are homotypic (combinations of the same name in different genera).

Even though not all are heterotypic, there are dozens of species with more than five synonyms in the Pleurothallidinae. In fact, there are currently eight species with 20 or more synonyms (Fig. 6). Even though some of those names surely represent the same species, the fact that authors have found the necessity of proposing so many names is highly indicative of their taxonomical complexity. Many so-called species complexes have been resolved during the Luerian era, be it by Luer himself or by other authors based on his works. But there are still many poorly understood species that will require close examination in the future.

Lepanthes and Stelis are among the genera Luer dedicated more monographic treatments. With over one thousand species each, they are both undoubtedly outstanding. Pérez-Escobar et al. (2017) found that the two have the highest diversification rates in the subtribe, and one of the highest in the Orchidaceae. The two genera are, however, intrinsically quite different. The flowers of Lepanthes species are relatively easily distinguished from one and other; the species are notably restricted in distribution, with many being narrowly endemic (Pupulin \& Bogarín 2012). On the contrary, the flowers of many Stelis species are difficult to distinguish, and many species are considered variable and very widely distributed. Whether this is true in nature or only our biased appreciation remains to be proven. Nevertheless, it is worth mentioning that the Lepanthes originated much earlier than species of Stelis sensu scricto (PérezEscobar et al. 2017), and therefore may have had more time to accumulate differences. We can expect many more novelties in both genera as they are studied more carefully.

Our intention, initially, was to use the species accumulation curve (Fig. 3) to estimate not only the number of additional species that can be expected to be discovered with further effort but also when we can expect to find a slower rate of species discovery. We can in fact estimate, based on the current rate of discovery, how many more species are likely to be recognized in the coming years. However, the growth in species numbers at this time is exponential and 


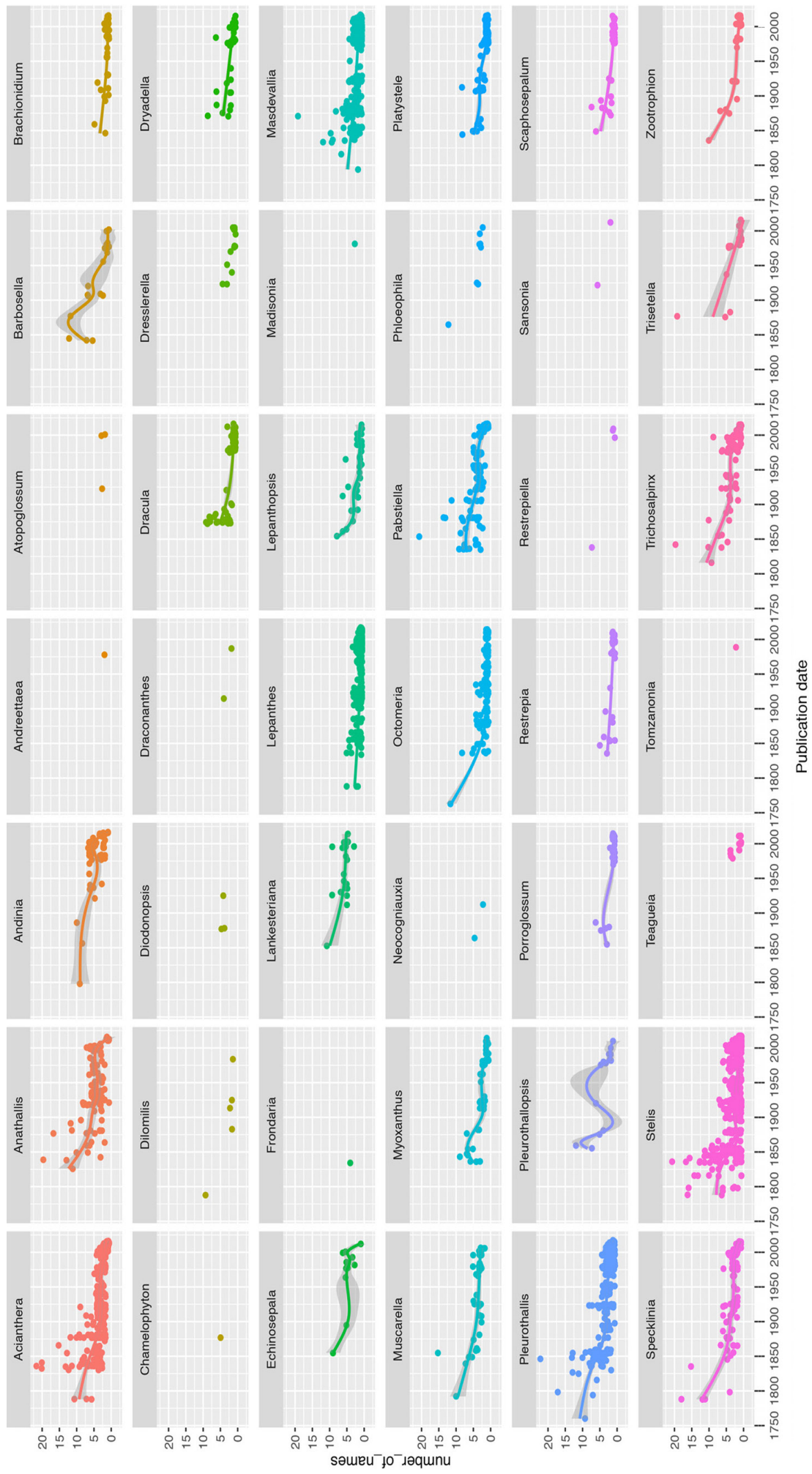

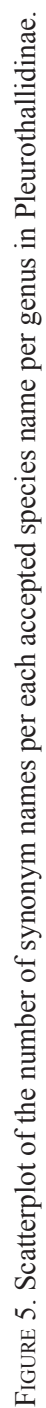




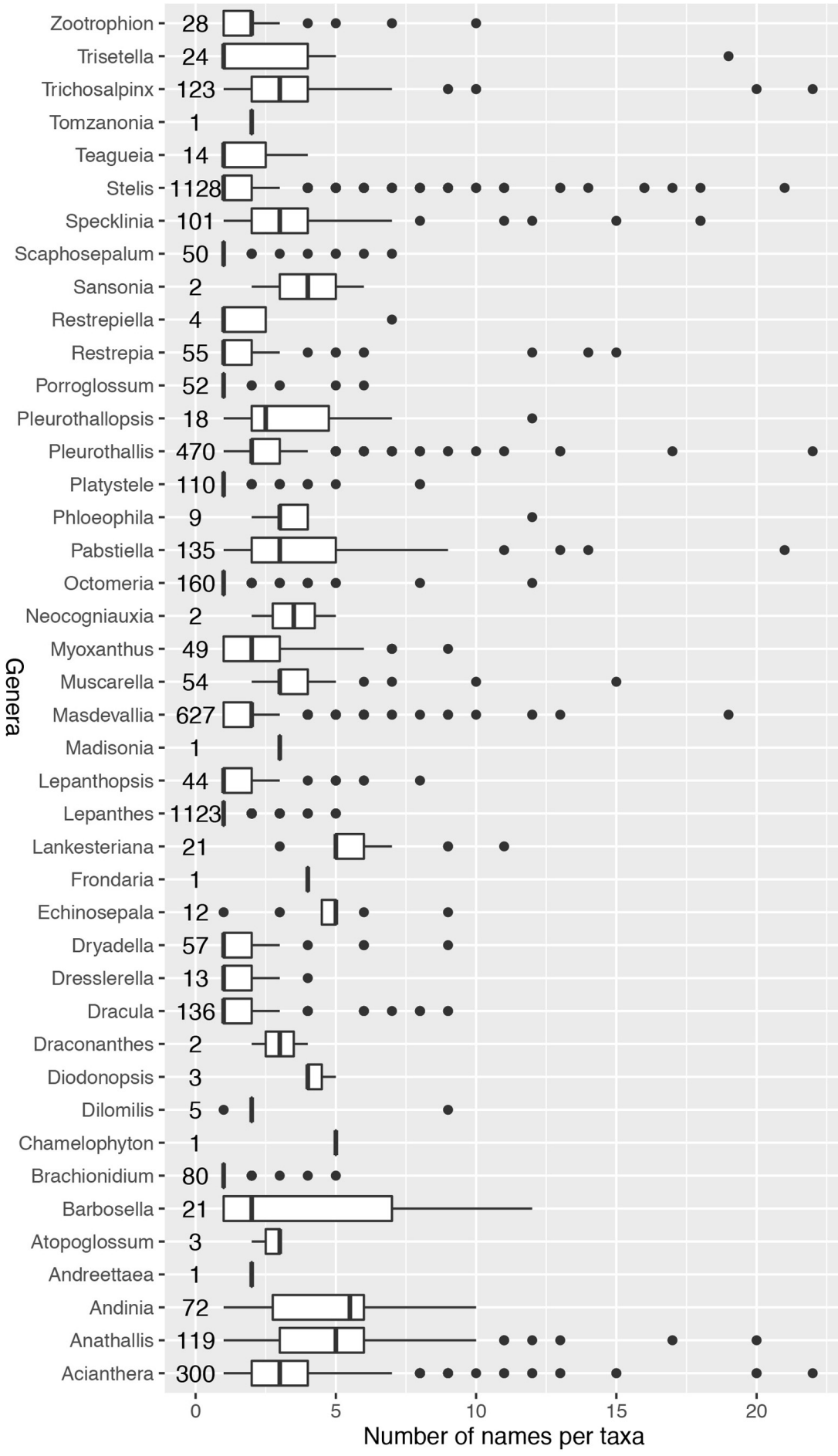

FIGURE 6. Boxplot of the number of synonym names per each accepted species name per genus in Pleurothallidinae. Showing the median and standard deviation. 
there seems to be no negative acceleration anywhere in sight. The rate of species description during the Luerian era has been about $85-90$ species per year, and there is nothing suggesting this rate will slow down anytime soon. If this trend continues, by the year 2026, we will have close to 6,000 accepted species in the Pleurothallidinae, and by the time the authors of this text turn eighty, we will be reaching 10,000 species in the subtribe.

Materials and methods. This work is based on an unpublished catalogue of the Pleurothallidinae which until the 1st of July 2017 included 12,133 taxa. The current analyses take $97.7 \%$ of those names into consideration. The remaining $2.3 \%$ represent cryptic taxa, mostly described under the generic name Pleurothallis, but also Lepanthes, Masdevallia and Stelis, and which have not yet been interpreted by any modern author. All analyses were done using R ( R core team, 2017) in R studio ( $R$ studio team, 2016). Scatterplot, box plot and histogram were built using the R package ggplot2 (Wickham, 2009).

ACKNOWLEDGEMENTS. This manuscript was prepared as part of a dedicatory issue commemorating the 95 th birthday of Carl Luer. The first author wishes to thank Franco Pupulin and Diego Bogarín for the inspiring discussions about pleurothallids.

\section{LiteratuRe Cited}

Barbosa Rodrigues, J. (1877). Genera et Species Orchidearum Novarum, I. Sebastianopolis, Brazil.

Barbosa Rodrigues, J. (1882). Genera et species Orchidearum Novarum II. Sebastianopolis, Brazil.

Cogniaux, A. C. (1896). Tribus VI. Pleurothallidinae Pfitz., p. 319-652. In Carl (Karl) Friedrich Philipp von Martius Flora Brasiliensis 3(4), 1-672.

Cogniaux, A. C. (1906). Addenda et Emendanda, p. 525-584. In Carl (Karl) Friedrich Philipp von Martius Flora Brasiliensis $3(6), 1-604$.

Karremans, A. P. (2016). Genera Pleurothallidinarum: an updated phylogenetic overview of Pleurothallidinae. Lankesteriana, 16(2), 219-241.

Lindley, J. (1842). Pleurothallis. Edwards's Botanical Register 28, 67-84.

Lindley, J. (1859). Folia Orchidacea. An enumeration of the known species of orchids. Pleurothallis. London, published for the author by J. Matthew.

Luer, C. A. (1975). Icones Pleurothallidinarum, Pleurothallis of Ecuador (Orchidaceae). Selbyana 1, 56-100.

Ossenbach, C. (2016). Orchids and Orchidology in the Antilles. Koeltz Scientific Books, Oberreifenber, Germany.

Pérez-Escobar, O. A, Chomicki, G., Condamine, F. L., Karremans, A. P., Bogarín, D., Matzke, N. J., Silvestro, D. \& Antonelli, A. (2017). Recent origin and rapid speciation of Neotropical orchids in the world's richest plant biodiversity hotspot. New Phytologist 215, 891-905.

Plumier, C. (1758). Plantarum Americanarum Fasciculus Octavus, Continens Plantas, quas olim Carolus Plumerius, Botanicorum Princeps, Detexit, Eruitque, Atque in Insulis Antillis ipse depinxit... Edited by J. Burmann. Amstelaedami, Petrum Schouten \& Lugd. Batav. Gerard Potvliet \& Theodor. Haak.

Pupulin, F. \& Bogarín, D. (2012). Lepanthes novae Tapantienses. Orchid Digest, 76(1), $20-29$.

R Core Team (2017). R: A language and environment for statistical computing. R Foundation for Statistical Computing, Vienna, Austria. URL https://www.R-project.org/.

RStudio Team (2016). RStudio: Integrated Development for R. RStudio, Inc., Boston, MA. URL: http://www.rstudio.com/. Wickham, H. (2009). ggplot2: Elegant Graphics for Data Analysis. Springer-Verlag New York. 
LANKESTERIANA 